\title{
Microphytoplankton Biozonation of Late Albian - Turonian succession in FAMO-1 well, Gongola Sub Basin, Upper Benue Trough, Nigeria
}

\author{
AMIEWALAN, FO; *LUCAS, FA \\ Department of Geology, University of Benin, Benin City, Nigeria \\ *Corresponding AuthorEmail: amiewalanflorence@gmail.com; drfalucas@gmail.com
}

\begin{abstract}
A comprehensive palynological (Dinoflagellate Cyst) study of 35 ditch cutting samples recovered from Late Albian to Turonian succession penetrated by Famo-1 well in the Gongola sub Basin, Upper Benue Trough, North East, Nigeria, generated biostratigraphically important dinoflagellate cyst species. Intervals ( $8300 \mathrm{ft}$. $-8330 \mathrm{ft}$.) in the lower part of the studied section were barren of dinoflagellate cysts. Interpretation of the first and last (FAD and LAD) appearance datum of the recovered dinoflagellate cyst assemblages allowed the erection of four informal dinoflagellate cyst assemblage biozones. The biozones in stratigraphically ascending order and their ages are as follows: Late AlbianCenomanian (Biozone I \& II), Turonian (Biozone III) and undiagnostic (Biozone IV). The ages of these zones based on stratigraphic positions and series of first occurrences of key species are from Late Albian-Turonian. An inner neritic palaeoenvironment was delineated based on the dominance of Peridinacean cysts over Gonyaulacacean cysts.
\end{abstract}

\section{DOI: https://dx.doi.org/10.4314/jasem.v22i8.25}

Copyright: Copyright $(92018$ Amiewalan and Lucas. This is an open access article distributed under the Creative Commons Attribution License (CCL), which permits unrestricted use, distribution, and reproduction in any medium, provided the original work is properly cited.

Dates: Received: 11 June 2018; Revised: 24 July: 2018; Accepted: 22 August 2018

Keywords: Turonian, Cenomanian, Biozone, palaeoenvironment.

Famo-1 well is one of the well drilled by Shell Nigeria Exploration and Production Company (SNEPCO) to a depth of about 3000m in 1999 which encountered some 33 billion standard cubic feet of gas and little oil. It's located in the Gongola Sub Basin, Upper Benue Trough, North Eastern part of Nigeria. It has an estimated area of $27390.25 \mathrm{~km}^{2}$ and lies between longitude $10^{\circ} 42^{\prime}$ '43.8' $\mathrm{E}$ and Latitude $10^{\circ}$ 07'03.9', $\mathrm{N}$. The Benue Trough has been considered part of the three-armed rift system which controlled the break-up of Gondwana (Burke et al., (1973); Hoffman et al., (1974). The Gulf of Guinea and the South Atlantic were the active arms of this triple junction along which spreading occurred and Africa separated from South America. The Benue trough represents the failed arm of a triple junction (aulacogen). Because of its tectonic setting, rift origin, and thick sedimentary pile, it has been considered an aulacogen (Hoffman et al., (1974); Olade, 1975). The Upper Benue Trough is sub-divided into three basins: the east-west trending Yola Basin (Yola Arm), the north-south trending Gongola Basin Gongola arm (It links the Benue Trough with the Bornu (Chad) Basin forming part of the West African Rift System) and the northeast-southwest trending Lau Basin (Main Arm) Guiraud, (1990); Dike, (2002). One of the inland basins in the Benue Trough believed to have petroleum potential is the Gongola Basin where samples were taken for this study. Geographically, it is sub-divided into lower, middle and upper portions and contains up to $6000 \mathrm{~m}$ of Cretaceous-Paleocene sediments of which those pre-dating the midSantonian were folded, faulted and uplifted in several places. There has been few thorough dinoflagellate studies for the Gongola sub Basin, Upper Benue Trough, North East Nigeria, when compared to the numerous research that have been done in the other basins in Nigeria, most especially the Niger Delta and Anambra Basins. The aim of this study is to add to the existing palynological records through the erection of dinoflagellate biozonation schemes which would promote better use of palynological events in age dating and correlation of wells. The precise objectives is to identify the palynomorph (Dinoflagellate cysts) abundance, their diversity and key taxa to interpret the age, produce biozonation scheme and to reconstruct the palaeoenvironment of deposition from the record of marine palynomorphs recovered from Famo-1 well.

Stratigraphy of the Upper Benue Trough: The stratigraphy of the Upper Benue Trough sediment resulted in the very extensive continental Bima Formation which directly overlies the basement complex. The part of the succession overlying the Bima Formation is largely marine, commencing with a transitional facies (Yolde Formation), which is heterolithic. (Carter et al., 1963) clearly illustrate the lithofacies and structure of the Gongola Basin which shows that the Zambuk Ridge demarcates this segment 
of the Benue Trough into two - the area adjoining the Chad Basin and the area to the south. On the Chad Basin area (North and northeast of the Zambuk Ridge), the systematic lithostratigraphic units are the Bima, Gongila, Fika and Gombe Formations. On the Zambuk Ridge, the units are the Bima, Yolde, Gongila, Pindiga with Gulani, Fika, Gombe and Keri-Keri Formations. In the south and southwest of the Zambuk Ridge, the units are the Bima, Yolde, Dukul, Jessu, Sekule, Numanha and Lamja Formations. The basin fill terminates with continental deposits associated with the withdrawal of the sea at End-Cretaceous, at which time a folding episode translated the depoaxis westwards to form the Keri-Kerri sub-basin.

\section{MATERIALS AND METHOD}

The available materials for this study are: Thirty-five ditch cutting samples from interval ranging from 6980 ft. $-8330 \mathrm{ft}$. Transmitted light Microscopes (Olympus binocular microscope) and Sony digital camera (14.1Mega Pixels).

Palynological Preparation: 35 samples were processed using standard palynological preparation for recovering acid insoluble organic- walled microfossils from sediments of Wood et al., (1996). 20g of sample were digested for 30 minutes in $38 \%$ hydrochloric acid to remove carbonate, followed by complete neutralization with distilled water and 72 hours in $40 \%$ hydrofluoric acid for removal of silicate, then neutralizes with distilled water. The extracts were washed through 10 microns nylon sieve mesh. The sieve-washed residues were oxidized for 30 minutes in $70 \% \mathrm{HNO}_{3}$ and 5 minutes in schulze solution to render the fossils translucent for transmitted light microscopy. The oxidized residues were rinsed in $2 \%$ $\mathrm{KOH}$ solution to neutralize the acid. Using a $125 \mu \mathrm{m}$ brass sieve, the residue was carefully sieved in an ultrasonic machine for a maximum of 5 minutes to improve palynomorphs recovery. The residues were stained with Safranin-O to increase the contract for study and photography. Two permanent slides per sample were prepared using Canada Basalm as mounting medium. The Palynological slides were examined using a transmitted light Binocular microscope. Visual estimation of various palynological slides components was made by traversing across each slide and coordinates. Photomicrographs of the palynomorphs were taken with the aid of Sony digital camera (14.1 mega pixels) (Plate I). The recovered palynomorphs species were identified with the aid of relevant publications such as Thusu and Van Der (1985); Abubakar et al., (1989); Moustafa and Lashin (2012); Uwins and Batten (1985) and web-based albums.

\section{RESULT AND DISCUSSION}

Dinoflagellate cysts were recovered from several levels of the penetrated intervals. In general, dinoflagellate cyst recovery was poor to moderate and thirty (30) identified dinoflagellate cysts were recovered. However, there was barren of dinoflagellate cysts in some depths of the well. (8300 $\mathrm{ft}$. $-8330 \mathrm{ft}$.). The preservation is moderate to good. Stratigraphic distribution of significant dinoflagellate cysts are displayed in (Table 1) and was developed based on the dinoflagellate cysts species identified in the well section.

Some key Dinoflagellate cysts recovered were: Chytroeisphaeridia chytroeides, Chytroeisphaeridia granulate, Coronifera oceanica, Ctenidodinium sp., Cyclonephelium distinctum, Cyclonephelium vannophorum, Exochosphaeridium sp., Florentina sp., Oligosphaeridium complex, Odontochitina costata, Palaeonhystrichophora sp., Spiniferites sp., Spiniferites ramosus, Systematophora sp., Subtilisphaera perlucida, Subtilisphaera cheit and Xenascus ceratioides. In over-all, the assemblages compare closely with those of similar age described by Abubakar et al., (1989); Below, (1981); Below, (1982); Uwins and Batten (1985); Williams, (1978); Thusu and Van Der (1985); Moustafa and Lashin (2012). Also recovered are Foraminifera test linings and Tasmanites.

Biozonation: Interpretation of the assemblage yielded four informal biozones. Biozones I and II ranges in age from Late Albian-Cenomanian, Biozone III is Turonian age while Biozones IV is undiagnostic due to absence of index dinoflagellate cysts (Table 2). The biozones were defined based on the use of the first and last occurrences of at least one species in the total assemblage in each zone. Ages of the delineated zones have been determined by comparison with accurately dated contemporaneous regional and interregional palynomorph assemblages in other areas. The top of the underlying zone is equivalent to the base of the overlying zone. The Biozones are discussed from the base to the top.

Biozone I: Stratigraphic interval: $7730 \mathrm{ft} .-8270 \mathrm{ft}$.: Definition: The top of this zone is marked by the first downhole occurrence of Spiniferites ramosus at 7730 $\mathrm{ft}$. The base of this zone is marked by the First appearance datum of Cyclonephelium distinctum at $8270 \mathrm{ft}$. Intervals $8300 \mathrm{ft}$. $-8330 \mathrm{ft}$. (Base of the well) were barren of dinoflagellate cysts. Other species recorded within this zone are Coronifera oceanica and Dinogynium sp. 
Age: The presence of Cyclonephelium distinctum, and Coronifera oceanica occurring within this zone was recorded as middle to late Albian by (Uwins and Batten (1985). Aboul Ela et al., (1994) suggested them as Late Albian - Early Cenomanian age while Thusu and Van Der (1985) used Spiniferites ramosus to age date Late Albian to Early Cenomanian sediment. In the present study, Late Albian - Early Cenomanian age was assigned to this assemblages.

Biozone II: Stratigraphic interval: $7460 \mathrm{ft}$. - $7730 \mathrm{ft.}$ : Definition: The top of this zone is marked by the first downhole occurrence of Cyclonephelium vannophorum / Subtilisphaera pirnaensis at $7460 \mathrm{ft}$. The base of this zone is marked by the First downhole occurrence of Spiniferites ramosus at $7730 \mathrm{ft}$. The assemblages in this zone include Cyclonephelium pausispinium, Kallosphaeridium cf. and Florentinia sp. Acme event of Cyclonephelium distinctum and Subtilisphaera pirnaensis.

Age: The following species - Subtilisphaera pirnaensis, Cyclonephelium distinctum, Cyclonephelium vannophorum and Florentinia sp. occurring in this zone was recorded as of AlbianCenomanian age by Uwins and Batten (1985); ElShamma and Baioumi (1993) referred these association to late Albian. The assemblages also compare closely with those of similar ages described by Below, (1981); Below, (1982); Williams, (1978). In this study, Late Albian - Early Cenomanian age was allotted to this assemblages. The first appearance of Cyclonephelium vannophorum was taken to demarcate the Late Albian - Early Cenomanian sediments from the younger ones.

Biozone III: Stratigraphic interval: $7280 \mathrm{ft} .-7460 \mathrm{ft}$.: Definition: The top of this zone is marked by the first downhole occurrence of Odontochitina costata at $7280 \mathrm{ft}$. The base is marked by the First downhole occurrence of Cyclonephelium vannophorum at 7460 $\mathrm{ft}$. Also characterizing this zone are Chytroeisphaerida granulate, Chytroeisphaerida sp., Millioudodium episomum, Oligosphaeridium complex, Leiosphaeridia sp. and Glabridinium apatelum. Acme event of Leiosphaeridia sp.

Age: Odontochitina costata is an important Turonian index form. Moustafa and Lashin (2012) had documented Odontochitina costata as Turonian age. Consequently, Turonian age was allocated to this zone.

Biozone IV: Stratigraphic interval: $6980 \mathrm{ft}$ - $7280 \mathrm{ft.}$ : Definition: The top of this zone is positioned at the first sample analyzed at $6980 \mathrm{ft}$. while the base is defined by the first downhole occurrence of Odontochitina costata $7280 \mathrm{ft}$. The species within this zone include Systematophora penicillata, Phoberocysta neocomica, Xenascus ceratioides, Chytroeisphaeridia chytroeides, Senegalinium iterlaaense $n$. sp. Palaeonhystrichophora sp., Senegalinium sp. and Exochosphaeridium sp. Acme event of Chytroeisphaeridia chytroeides. Other species present in the zone not represented in the range chart include Homotryblium sp. and Leptodinium cf.

Table 1: Range chart of some important dinoflagellate cysts recovered in Famo-1 well.

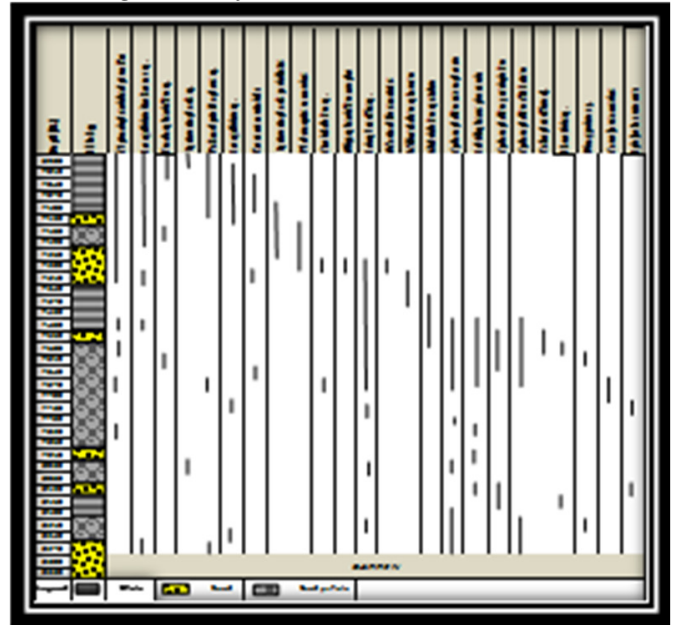

Age: Undiagnostic. Age diagnostic dinoflagellate cysts taxa were not in the right interval within this zone hence no age conclusions (indeterminate) can be made in the upper part of the well. Table 2 shows the dinoflagellate cysts biozonation recognized in Famo-1 well.

Table 2: Dinoflagellate cysts biozonation recognized in Famo-1 well

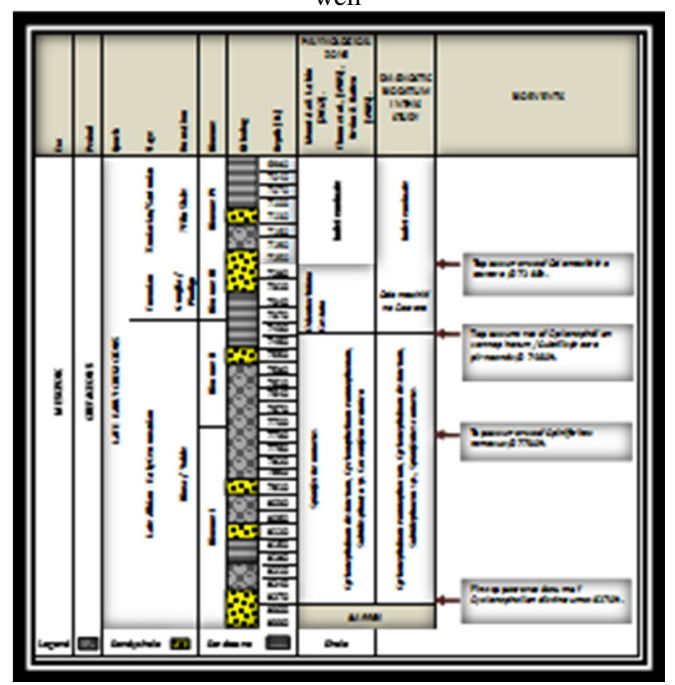


Paleoenvironmental interpretation: Based on the dinoflagellate cysts recorded in the studied section, the Peridinacean cysts make up $72 \%$ while the Gonyaulacacean make up $28 \%$ of the total assemblage. The high Peridinacean dinoflagellate cysts species abundance and diversity indicate shelfal environment and are useful salinity index. The increase of Peridinacean dinoflagellate cysts indicates reduced salinity and close proximity to the shoreline, whereas Gonyaulacacean cysts are associated with open marine conditions. Davey, (1970); Harland, (1973). Chitinous foraminifera test lining also present are planispiral evolute which are of benthonic forms and their abundance indicates a flourishing environment, most probably an inner neritic environment. Thus further confirming the near-shore marine environment. From the above, the paleodepositional environment is deduced to be Nearshore/inner neritic environments.

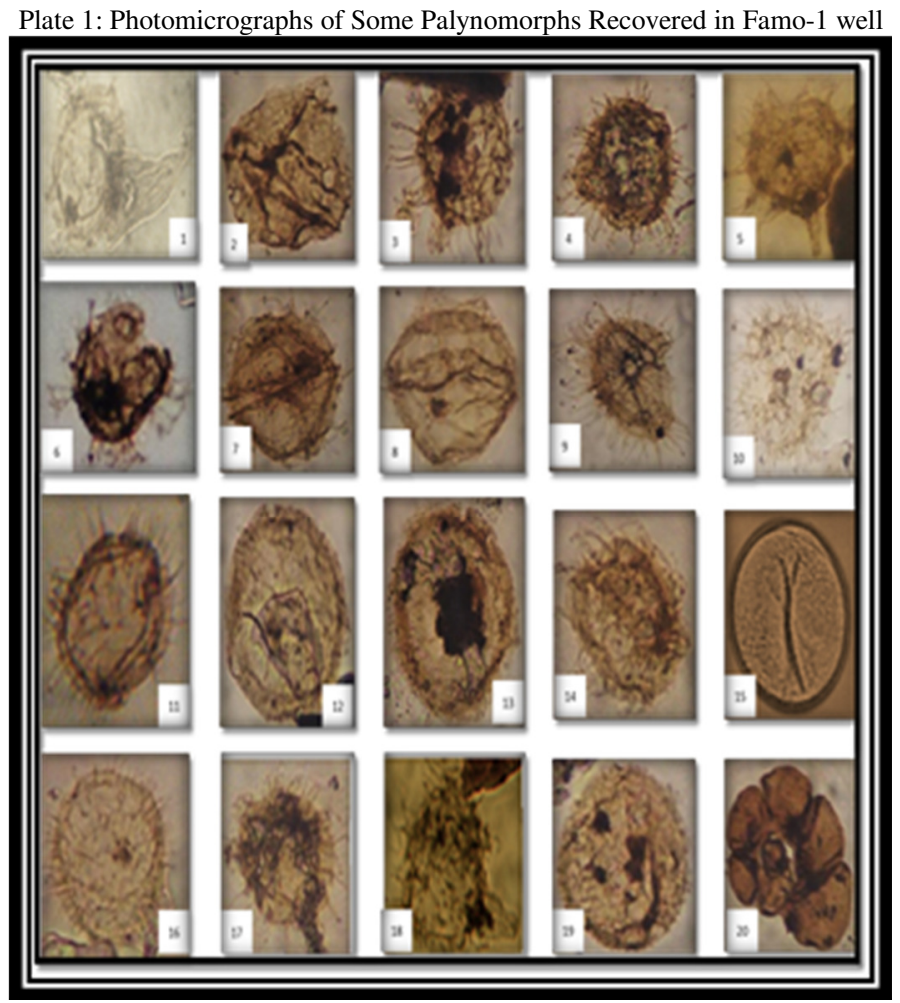

Explanation of plate 1: 1. Odontochitina costata 2. Palaeonhystrichophora sp. 3\&4. Systematophora penicillata 5. Florentinia sp. 6. Oligosphaeridium complex 7\&8. Subtilisphaera sp. 9. Systematophora penicillata 10. Spiniferites sp. 11. Ctenidodinium sp. $12 \& 13$. Cyclonephelium distinctum 14. Spiniferites ramosus 15. Tasmanites 16. Exochosphaeridium sp. 17. Coronifera oceanica 18. Florentinia sp. 19. Cyclonephelium vannophorum 20. Foraminifera test lining

Conclusion: The evaluation of dinoflagellate cyst recovered from Famo-1 well has allowed for the erection of four informal assemblage biozones, Late Albian-Cenomanian age was assigned to biozone I \& II, Turonian age assigned to biozone III and biozones IV was undiagnostic due to lack of index marker present in the stratigraphic interval. An inner neritic palaeoenvironment of deposition was delineated for the interval studied.

Acknowledgment: The authors are grateful to Shell Petroleum Development Company, for providing the ditch cutting sample used for these findings. Acknowledgements are also made to Mrs. Efe Mude of SPDC for her assistance during the collection of all the materials used for this Project.

\section{REFRENCES}

Aboul Ela, NM; Dave Shaw; Ragab, SE (1994). Palynostratigraphy of the Bahariya Formation in the subsurface of the Salam oil field, north Western Desert, Egypt. Proc. 13th EGPC Petrol. Confr. Vol. 1, p. 381-400.

Abubakar, MB; Luterbacher, HP; Ashraf, AR; Ziedner, R; Maigari, AS (1989). Late Cretaceous palynostratigraphy in the Gongola Basin (Upper Benue Trough, Nigeria). Journ. of African Earth Sci. vol. 60 , p. $19-27$

Below, R (1981). Dinoflagellaten-Zystem aus dem oberen Hauterive bis Unteren Cenoman Sud- 
Weat-Marokkos. Palaeontographica vol. 176, p. 145.

Below, R (1982). Scolochorate Zystem der Goanyaulacaceae (Dinophyceae) aus der Unterkriede Marokkos. Palaeontographica B, vol. 182, p. 1-51.

Burke, KCB; Dessauvagie, T F J; Whiteman, A J (1973). The opening of the Gulf of Guinea and the Geological History of the Benue Depression and Niger Delta. Nature phys. Sci vol. 233 (38), p. 5155

Davey, RJ (1970). Non-calcareous microplankton from the Cenomanian of England, northern France North America. Part II. Bull. Br. Mus. (Nat. Hist.), Geol. Vol. 18, p. 33-397.

Dike, EFC (2002). Sedimentation and tectonic evolution of the upper Benue Trough and Bornu Basin, NE Nigeria. In: Nig min, Geosci, Soc. $38^{\text {th }}$ Annual internat. Conf. Port Harcourt, Nigeria.

El-Shamma, AA; Baioumi, AE (1993). Palynostratigraphic zonation of northern Western Desert, Egypt. Egypt. Journ. Geol., vol 37(2): p. 247-274
Harland, R (1973). Dinoflagellate cysts and acritarchs from the Bearpaw Formation (Upper Campanian) of Southern Alberta, Canada, Paleontology vol. 16, p. 665-706.

Moustafa, TF; Lashin, GA (2012). Aptian - Turonian Palynomorphs from El-waha-1 well, Southwestern Part of the Western Desert, Egypt.

Thusu, B; Van Der, JGE (1985). Early Cretaceous (Neocomian - Cenomanian) palynomorphs: Journal of micropaleontology, vol. (4) (1) p. 131150.

Uwins, PJR; Batten, DJ (1985). Early Cretaceous palynomorphs of northeast Libya. El Arnauti, A. et. al., (Eds.).

Wood, GD; Gabriel, AM; Lawson, JC (1996). Palynological techniques - processing and microscopy. In: Jansonius, J. and McGregor, D. C. (Eds) Palynology: principles and applications, American Association of Stratigraphic Palynologists Foundation, vol. 1, p. 29-50. 